I would like to thank C. S. Houston and W. E. Renaud for their comments on the manuscript, the Canadian Wildlife Service for permission to use data collected during the past summer and J. B. Gollop for his assistance in obtaining data.
GOLLOP J. B. 1971. Summer records of Huc. sonian Godwits near Saskatoon, Saskatchewar Blue Jay 29(3):132-134.

${ }^{2}$ HARRIS W. C. and V. J. LIEFFERS. 197 Foam Lake - natural history notes and speci lists. Canadian Wildlife Service Unpublishe Report. 21 pp.

"VINCENT J. 1966. Red Data Book, Volume The Aves. International Union For Conse vation of Nature and Natural Resources.

\title{
ROCK WREN AT SPRAGUE, MANITOBA
}

\author{
by DAVID R. M. HATCH and HERBERT W. R. COPLAND*
}

On the morning of October 11 , 1972, a Manitoba Museum of Man and Nature field party consisting of Dr. Robert Wrigley, Jack Dubois, Calvin Cuthbert and the authors identified a Rock Wren (Salpinctes obsoletus) at the farmhouse of Dr. George Lammers, 9 miles north of Sprague, Manitoba. The junior author's attention was attracted by the melodious song, which was unfamiliar to him, however he did not locate the bird. Approximately one hour later Cuthbert observed the bird and called the authors. The bird was wary but reluctant to leave the immediate locale of the farm buildings. Cuthbert and the authors, using binoculars and a telescope obtained excellent observations of the wren and the following details were noted. The bird was the size of a White-breasted Nuthatch. The tail, which was finely barred with grey and brown throughout its length, had a broad terminal band of black, bordered on the

\footnotetext{
* Manitoba Museum of Man and Nature,

190 Rupert Avenue,

Winnipeg, Manitoba.

R3B ON2
}

outside by orange buff. Besides th key distinguishing feature, the rum was rusty, the breast finely streake the crown and back grey-brown an the bill about $1 / 2$ inch long and curve slightly downward.

The bird kept returning to a pile scrap lumber; however, it als frequented a derelict binder and ty deserted buildings. All five observe had the bird under observation an were able to verify details. The seni author was previously familiar wi the species having observed Ro Wrens in Saskatchewan and $t$ western United States. The bird, bei seen so far east of its normal range ar at such a late date, was collected substantiate the presence of the speci in the province and is specimen $N$ MMMN 3236 in the study skin colle tion of the Manitoba Museum of $\mathbf{M}$ and Nature. It proved to be an adi male. Godfrey in listing the $e$ tralimital records for this species Canada gave Churchill as the mo easterly record. ${ }^{3}$ Since th publication, there have been two $\mathrm{C}$ 
tario reports. One of which was at Ear Falls and, like the most recent Manitoba record, the specimen was obtained in October, 1972, (Laura Howe, pers. comm.). The other was of a specimen collected at Port Weller on Dec. 7, 1964.

There are three additional records of Rock Wrens in Manitoba. One was initially seen on June 29, 1956, at Churchill, Manitoba, by Dr. David Sergeant and John Crosby.' Crosby saw the bird subsequently on July 4 and July 7 and Eva Beckett saw and heard the bird daily between July 5 and July 23. On July 18, two Rock Wrens were seen by Beckett. She observed one of the birds carrying food on August 1 and August 2. "On August 3 the bird appeared to be in a state of great anxiety at Beckett's approach, but no young were found. No wrens were seen in the area on August 4 or thereafter." Although no actual nest was found, there is every indication the birds were nesting (pers. corres. Crosby and Beckett, 1972).

Rock Wrens were again recorded at Churchill when a "pair returned to Churchill on 23 May, 1957, but were feen only once. This disappearance nay have resulted from a severe nowstorm a few days later." 4 "This obervation was originally made by Mike Stefishyn and confirmed by Mrs. Eva Beckett. Mrs. Beckett's records show he date was May 24, and not May 23 is reported by Jehl and Smith Beckett, pers. corres. 1973). ${ }^{4}$

On May 7, 1970, Mr. and Mrs. Angus H. Shortt saw a Rock Wren in heir houseyard at 101 Morier Avenue, Winnipeg, Manitoba. Shortt vrote: "it was busily engaged in probing openings and crevices in a pile f lumber stacked against our garage. Movements were typically wren-like vith at times, the agility of a nuthatch .. The outstanding feature was the old terminal bands of buff (almost an range-buff) and black on the tail.".3 his bird was observed for ap- proximately 8 minutes through $8 \mathrm{X}$ binoculars at distances of 20 to 50 feet.

The Rock Wren is a western species which normally frequents hot, dry, rocky habitat; however, the Manitoba records are all from areas atypical of the bird's normal habitat requirements. The species has now been recorded four times in Manitoba (Fig. 1) and on the basis of the above records must be considered an occasional wanderer to the province.

'CROSBY, J., and E. BECKETT. 1957. Rock Wren at Churchill, Manitoba. Can. Field-Nat. 71:82-83.

${ }^{2}$ GARDNER, K. 1970. Wild Wings. Winnipeg Tribune. May 30, 1970.

"GODFREY, W. E. 1966. The birds of Canada. National Museum of Canada. Bull. 203, Biol. Series No. 73, Ottawa, 428 pp., 69 colour plates.

tJEHL, J. R. Jr. and B. A. SMITH. 1970. Birds of the Churchill region. Special Publication No. 1. Manitoba Museum of Man and Nature, Winnipeg, Manitoba.

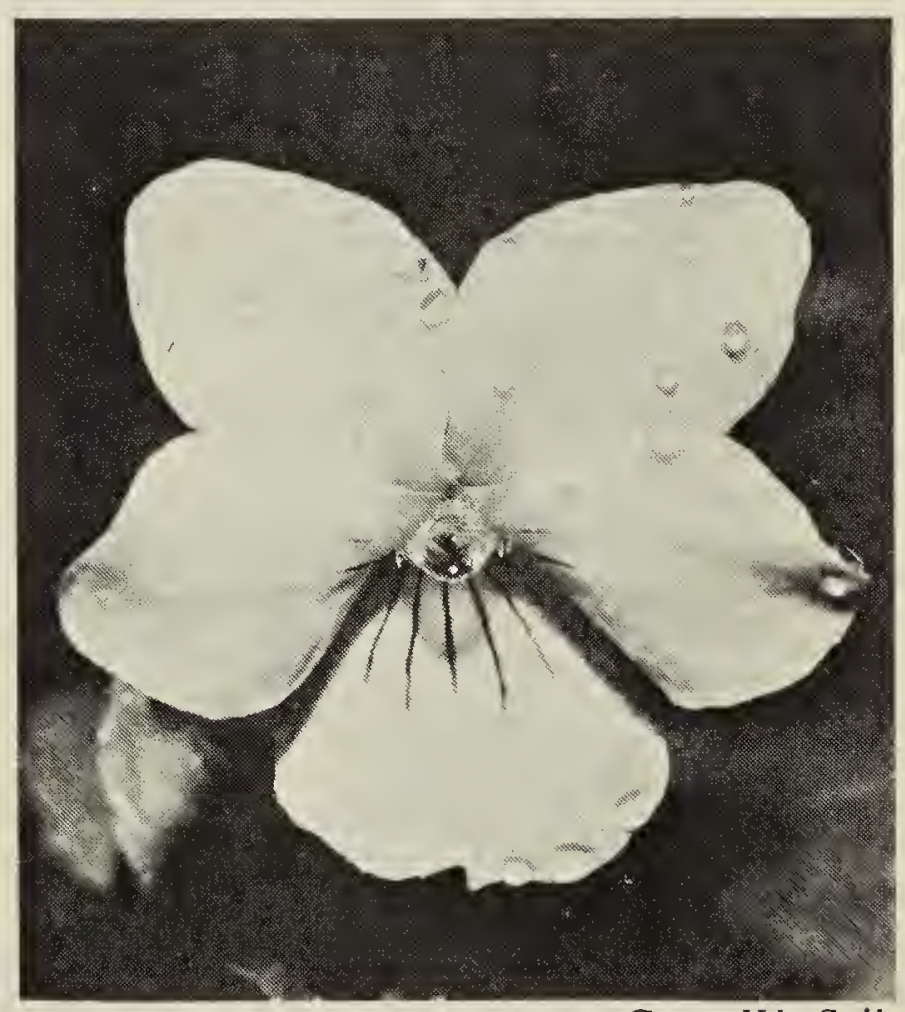

Western Canada Violet 